DOI: $110.2478 /$ ausp-2018-0023

\title{
Nóra Csontos - Csilla Ilona Dér Pragmatika a magyar mint idegen nyelv oktatásában \\ (Pragmatics in Teaching Hungarian as a Foreign Language), pp. 92 \\ Budapest: Károli Gáspár Református Egyetem - L’Harmattan Publishing House, 2018
}

\author{
Review by \\ Zsuzsanna AJTONY \\ Sapientia Hungarian University of Transylvania (Cluj-Napoca, Romania) \\ Department of Humanities \\ ajtonyzsuzsa@uni.sapientia.ro
}

For a long time, pragmatics, and especially studies in speech acts "have suffered from astonishing ethnocentrism" (Wierzbicka 2003: 25); the observations made by researchers on the English language use having been extended to language use in general. The book presented in this review continues the line of studies and books that go against this trend (see, for instance, Thomas 1983, Wierzbicka 1985, Holmes 1995) as it brings into discussion pragmatic knowledge also from a Hungarian perspective. A result of a fruitful collaboration between Károli Gáspár University of the Reformed Church (Budapest, Hungary) and Ferenc Rákóczy II Transcarpathian Hungarian Institute (Beregszász, the Ukraine), the series of books on Hungarian linguistics - edited by Orsolya Nádor - is designed to offer help to teachers of Hungarian as a foreign language.

Heavily relying on contemporary international and Hungarian research, the present volume presents the most important and basic information on the stateof-the-art of pragmatics through an intercultural lens. Pragmatics is regarded as a verbal activity embedded in diverse cognitive, social, and cultural contexts. In twelve chapters, the authors, Nóra Csontos and Csilla Ilona Dér, advance from more general information on pragmatics as a branch of linguistics towards the peculiarities of Hungarian pragmatics. Starting with a general description of the verbal activity, through chapters on context, written and oral discourses, deixis and co-reference, Grice's conversational maxims and theory of implicature, 
speech acts, and pragmatic politeness, the second main part of the volume gives an overview of the most significant results of research on politeness and speech acts in Hungarian, especially highlighting the questions of requests, refusals and praises, and ways of representing these speech acts in three different student's books teaching Hungarian as a foreign language (MagyarOK, Lépésenként magyarul [Step by Step in Hungarian] and Halló, itt Magyarország [Hello, This Is Hungary]). Chapters 10 and 11 summarize the general and communicative (linguistic, sociolinguistic, and pragmatic) competences that a language learner is supposed to acquire and the deficiencies of pragmatic competence, i.e. pragmatic failure and pragmatic mistakes. Finally, the book concludes with a list of topics (frames, scripts), strategies, and discourse types that appear in the Common European Framework of Reference (CEFR 2001) for all the levels, starting with A1 (beginner level) up to C2 (proficiency level), enlisting the social and cultural competences that need to be acquired while learning a foreign language: everyday living, living conditions, interpersonal relations, including relations of power and solidarity, values, beliefs and attitudes (here special emphasis is laid on those situations which might cause offence or which are different in other cultures), body language, and social conventions.

One of the strengths of the volume is that it draws attention to the Hungarian verbally and culturally defined, phonological, grammatical differences, pragmalinguistic and sociopragmatic strategies that need to be acquired when learning it as a foreign language. First and foremost, a student of Hungarian needs to be aware of the linguistic markers of attitude deixis, i.e. the T/V distinction present in the more or less formal ways of addressing (te/ön/maga, similar to the German $d u / S i e$ or the French $t u /$ Vous). In addition, there are typical Hungarian formal greetings, such as Csókolom ('I kiss you'), Kezét csókolom ('I kiss your hand'), or special formal requests of the type tetszik + infinitive ('like + infinitive') (e.g. Tetszik kérni? [Would you like some?], Tetszik venni? [Would you like to have some?]. Similarly, direct refusal of a request, explicit way of saying 'no' counts as very impolite in Hungarian. Instead, Hungarians prefer to use three main strategies: giving explanations for the refusal, denial, and expressing sorry. The discussion concludes with the remark that the degree of directness is in strong connection with the cultural habits.

The phonological differences in the expression of spatial deixis also require special attention from learners of Hungarian as the deictic expressions to show location close to the speaker, i.e. to the deictic centre, require the front unrounded vowel /i/ (itt 'here' and ez 'this'), while deictic expressions pointing to entities at a distance from the speaker require the open back vowel /a/ or /o/ (ott 'there', $a z$ 'that'). This feature is very similar to English deictic expressions, and therefore it might foster English students' learning Hungarian. 
The book also draws attention to the correct use of the greeting hello in Hungarian, used for both meeting and departing, while in English it is used only for the former situation. Being unaware of this distinction may lead to pragmalinguistic failure (see also Csatlós 2014).

Sociopragmatic failure (Leech 1983) can similarly occur if students of a foreign language are not taught about certain topics that are considered taboos in the target culture. They need to learn to be culturally sensitive to acceptable vs nonacceptable topics in a given situation. In Hungarian, for instance, it is not fitting to talk about religious, political, racial, sexual topics, financial matters in formal situations, even if it is possible to touch upon these problems more openly in the learner's culture.

As Wierzbicka claims (2003: viii), research into differences between cultural norms associated with different languages is essential for peaceful co-existence, mutual tolerance, necessary understanding in the workplace and in other walks of life in the increasingly "global" and yet in many places increasingly diversified world. Today, when Hungarian is studied by a growing number of learners all over the world, the book especially addressing teachers of Hungarian as a foreign language is an invaluable tool in making them and their students aware of the generalities and pitfalls that might occur in their teaching practice.

\section{References}

Csatlós Krisztina 2014. Angolul tanuló magyar hallgatók pragmatikai hibái egy empirikus kutatásról [Pragmatic Failure of Hungarian Students Studying English - An Empirical Research]. Economica 7(4): 13-24.

Holmes, Janet 1995. Women, Men and Politeness. London: Longman.

Leech, Geoffrey. 1983. Principles of Pragmatics. London: Longman.

Thomas, Jenny 1983. Cross-cultural pragmatic failure. Applied Linguistics 4(2): 91-112.

Wierzbicka, Anna. 1985. Different cultures, different languages, different speech acts: English vs Polish. Journal of Pragmatics 9: 145-78.

2003. Cross-Cultural Pragmatics. Second edition. Berlin-New York: Mouton de Gruyter. 